\title{
PENINGKATAN KEMAMPUAN MEMBACA PERMULAAN MELALUI KARTU KATA DAN GAMBAR PADA TAMAN KANAK-KANAK
}

\author{
Ismayanti Muis ${ }^{1}$ \& Azizah Amal ${ }^{2}$ \\ Pendidikan Guru Pendidikan Anak Usia Dini, Universitas Negeri Makassar
}

\begin{abstract}
:
The aim of this research is to find out how to improve the ability to start reading through word cards and pictures in Tadika Ceria Kindergarten BTN Kodam VII Wirabuana group B2. This research approach is a qualitative approach. This type of research is a classroom action research which consists of 4 components in each cycle, namely planning, implementing, observing, and reflecting. The focus of this research is the ability to read at the beginning, and through word cards and pictures. This research was conducted in 2 cycles consisting of 2 meetings per cycle. The research subjects were group B2, amounting to 8 students. Data collection was carried out through observation and documentation. The results of the teacher observation research cycle 1 were in the poor category and cycle II was in the good category.
\end{abstract}

Keywords: Read the beginning of the word card and picture.

\begin{abstract}
Abstrak:
Tujuan yang ingin dicapai dalam penelitian ini adalah untuk mengetahui caraMeningkatkan kemampuan membaca permulaan melalui kartu kata dan gambar di Taman Kanak-kanak Tadika Ceria BTN Kodam VII Wirabuana kelompok B2. Pendekatan penelitian ini adalah pendekatan Kualitatif.Jenis Penelitian ini adalah penelitian tindakan kelas (PTK) yang terdiri dari 4 komponen dalam setiap siklus yaitu perencanaan, pelaksanaan, pengamatan, dan refleksi. Fokus penelitian ini adalah kemampuan membaca permulaan, dan melalui kartu kata dan gambar. Penelitian ini dilakukan 2 siklus yang terdiri dari 2 pertemuan setiap siklusnya. Subjek penelitian adalah kelompok B2 yang berjumlah 8 orang anak didik. Pengumpulan data dilakukan melalui observasi dan dokumentasi.Hasil penelitian observasi guru siklus 1 berada pada kategori kurang dan siklus II berada pada kategori baik.
\end{abstract}

Kata Kunci: Membaca permulaan kartu kata dan gambar. 


\section{PENDAHULUAN}

Pengembangan kemampuan membaca berhubungan langsung dengan tingkat bimbingan orang dewasa dalam menggunakan bahasa dan menekankan hubungan tulisan dengan abjad, kata, dan pesan. Persoalan yang terpenting untuk mengajarkan membaca pada anak adalah bagaimana cara mengajarkan ke anak sehingga anak menganggap kegiatan belajar mereka seperti bermain dan bahkan berbentuk sebuah permainan menarik, jadi kegiatan atau pembelajaran membaca di Taman Kanak-kanak dapat dilaksanakan selama masih sesuai dengan karakteristik anak, yakni bermain sambil belajar.

Berdasarkan observasi awal di lapangan yang dilakukan di Taman Kanak-kanak Tadika Ceria BTN Kodam VII Wirabuana. Dalam hal proses mengajar telah diperoleh data bahwa perkembangan bahasa dalam hal kemampuan membaca permulaan, masih sangat rendah, beberapa anak masih pasif, beberapa anak belum mampu membaca permulaan tetapi hanya menghafal saja, media yang digunakan hanya poster serta pembelajaran yang digunakan oleh guru tidak bervariasi atau monoton, sehingga anak mengalami kebosanan.

Kartu kata dan gambar adalah cara yang dapat membantu perkembangan peserta didik. Kata adalah gabungan huruf yang memiliki makna. Dan gambar adalah perpaduan antara titik, garis, bentuk, dan warna untuk membuat suatu objek. Dalam hal ini banyak anak didik belum mampu, melakukan kegiatan yang menunjukkan anak mampu mengenal benda dengan menghubungkan satu benda dengan benda yang lain dan anak belum mampu melakukan kegiatan yang menunjukkan anak mampu mengenal benda dengan menghubungkan nama benda dengan tulisan. Jadi dengan menggunakan kartu kata dan gambar dapat meningkatkan kemampuan membaca permulaan pada anak.

Berkaitan dengan hal di atas, maka yang lebih penting adalah bagaimana menjadikan anak mampu membaca dengan baik, olehnya itu untuk menjadikan anak mampu membaca maka peran orang tua dan guru memilih media yang dapat membantu mengasah kemampuan anak peserta didik untuk itu, tindakan awal yang perlu di tempuh seorang pendidik adalah membantu kebiasaan dan kegemaran membaca melalui media yang dipilih. Media yang disertai dengan gambar-gambar yang menarik, mudah dibuat, harganya murah, serta huruf yang jelas sehingga memudahkan anak mempelajarinya. gambar memiliki kekuatan besar dalam merespon otak anak, anak akan mudah memahami kata-kata yang dipelajarinya dengan melihat gambar.

Menurut Masri (2008:4) mengemukakan bahwa."Membaca Permulaan menekankan pengkondisian anak untuk masuk dan mengenal bacaan sehingga belum sampai pada pemahaman yang mendalam pada materi bacaan". Membaca untuk anak usia dini disebut dengan membaca permulaan anak. Asroriyah (2014) memberi gambaran bahwa kemampuan membaca permulaan adalah kemampuan untuk menerjemahkan simbol dalam bentuk bunyi dan menunjuk atau mengambil huruf dan melafalkan huruf, mengenali kata dengan menyebutkan huruf-huruf yang ada di kata dan merangkai huruf membentuk kata, dan memahami makna dan maksud bacaan dengan mencocokkan gambar dengan kata dan membaca gambar tuliskan kalimat sederhana. Kemampuan membaca permulaan menjadi kemampuan dasar membaca anak dengan mengenal konsep huruf, kata, dan kalimat.

Penggunaan Alat Permainan Edukatif (APE) dalam mengembangkan kemampuan membaca anak sangat penting dimana APE berfungsi sebagai media yang tepat dalam menstimulasi kemampuan anak (Syamsuardi: 2012) dan kartu kata merupakan salah satu 
bentuk APE, yang menggunakan media kartu. Menurut Suharso dan Retnoningsih (2009: 226), Kartu adalah kertas tebal yang berbentuk apa saja dan sesuai keperluan seperti: tanda anggota, lingkaran, dan lain-lain. Penggunaan kartu kata ini beranjak pada pemahaman bahwa anak pada usia 4-5 tahun masih berpijak pada "Belajar Melalui Bermain" atau "Bermain Sambil Belajar" (Tadkiroatun, 2009: 98). Bermain untuk landasan membaca permulaan anak usia 4-5 tahun dapat berupa pembacaan cerita bergambar dengan sedikit tulisan, permainan acak huruf, permainan tata huruf, mencari label yang sama, menebak tulisan, membaca gambar, mencocokkan huruf, mencari huruf yang sama, permainan silabel, mengecap huruf, mengelompokkan huruf, mengenal huruf yang hilang, dan kegiatan lain yang memberi kesempatan anak mengenal simbol utuh. maupun pasial (dalam bentuk guntingan kata), (Tadkiroatun, 2009: 112). Pilihan model permainan ini sangat tergantung pada kreativitas guru yang mengajar.

\section{METODOLOGI}

Pendekatan yang digunakan dalam penelitian ini adalah pendekatan Kualitatif yang bertujuan untuk mengungkapkan masalah yang diteliti secara menyeluruh, luas, dan dalam khususnya mengenai kemampuan membaca permulaan melalui kartu kata dan gambar. Penelitian ini dilaksanakan di Taman Kanak-Kanak Tadika Ceria kelompok B2 Kodam VII Wiranuana Kota Makassar. Subjek dalam penelitian adalah Kelompok B2. Di Taman Kanak-kanak Tadika Ceria BTN Kodam VII Wirabuana Kota Makassar pada semester I tahun ajaran 2018/2019 dengan jumlah pengajar I guru dan 8 anak didik, laki-laki terdiri 3 orang anak, dan perempuan terdiri 5 orang anak.

Penelitian tindakan kelas ini dirancang untuk dilakukan dalam 2 (dua) siklus, yang setiap siklusnya diadakan 2 (dua) kali pertemuan. Serta tiap siklus mempunyai 4 Tahapan, yaitu Planning (rencana), Action (tindakan), Observation (Pengamatan), Reflection(refleksi). Teknik pengumpulan data adalah proses untuk menghimpun data yang diperhatikan relevan serta akan memberikan gambaran dari aspek yang akan diteliti. Teknik pengumpulan data yang digunakan adalah metode observasi dan dokumentasi.

Observasi/pengamatan, digunakan dalam rangka mengumpulan data dalam suatu penelitian. metode observasi digunakan untuk mengukur kemampuan membaca permulaan anak melalui kartu kata dan gambar. Digunakannya metode observasi ini karena subjek yang diteliti adalah anak Taman Kanak-kanak yang perlu diperhatikan oleh peneliti mengamati dan mencari data yang sebenarnya.

Dokumentasi, ini digunakan dalam upaya melengkapi data-data yang telah diperoleh berupa gambaran penelitian, keadaan populasi dan data yang digunakan melalui dokumendokumen yang berhubungan dengan permasalahan.Teknik analisis data yang digunakan untuk menjawab rumusan masalah atau menguji hipotesis yang telah dirumuskan dalam proposal. Menurut Badgan (Sugion,2016: 244) : Analisis data adalah proses mencari dan menyusun secara sistematis data yang diperoleh dari hasil wawancara, catatan lapangan, dan bahan-bahan lain, sehingga dapat mudah diahami dan temuannya dapat diinformasikan kepada orang lain. Peneliti menggunakan Analisis deskriptif kualitatif. Analisis deskriptif kualitatif adalah suatu penelitian yang digunakan untuk mengolah data yang dimulai dari mengamati kemampuan anak, kemampuan mencatat dalam lembar observasi yang disedia- 
kan dengan maksud memberikan gambaran yang jelas, sehingga mempermudah untuk melakukan pengumpulan data.

\section{HASIL DAN PEMBAHASAN}

Kemampuan membaca permulaan usia 5-6 tahun di Taman Kanak-kanak Tadika Ceria BTN Kodam VII Wirabuana Kota Makassar sebelum ada tindakan belum berkembang dengan maksimal. Hal ini dikarenakan guru kurang melakukan pembelajaran yang melibatkan keaktifan anak, suasana pembelajaran kurang menerapkan assensi bermain dan penggunaan metode yang bersifat monoton yang menyebabkan anak menjadi bosan. Namun, setelah di terapkannya pembelajaran kartu kata dan gambar untuk mengembangkan kemampuan membaca permulaan, maka terjadi peningkatan dengan langkah-langkah sebagai berikut:

1. Lepaskan kepingan-kepingan kartu kata

2. Acak kepingan-kepingan kartu kata

3. Mengajak anak untuk bermain kartu kata

4. Memberikan tantangan kepada anak untuk menyusun kepingan kartu dengan tepat, menggunakan hitungan angka 1-10 atau stopwatch.

Peningkatan cara mengajar guru sangat meningkat secara signifikan. Hal ini dapat dilihat bahwa pada siklus I, Lepaskan kepingan-kepingan kartu kata berada dalam kategori kurang, karena saat melakukan proses pembelajaran anak yang melepaskan kepingankepingan kartu kata dan gambar tersebut. Acak kepingan kartu kata berada dalam kategori cukup, karena pada saat proses pembelajaran guru mengajak kepingan-kepingan kartu kata hanya sebagian saja. mengajak anak untuk bermain kartu kata berada dalam kategori kurang, karena pada proses pembelajaran guru tidak mengajak anak untuk bermain kartu kata dan gambar, melainkan guru hanya langsung membagikan kartu kata dan gambar tersebut. memberikan tantangan kepada anak untuk menyusun kepingan kartu dengan tepat, menggunakan hitungan angka 1-10 atau stopwatch. berada dalam kategori baik, karena guru memberikan tantangan kepada anak dengan cara menarik, sehingga anak termotivasi dan tertarik untuk menyusun kepingan kartu kata dan gambar. Menunjukkan anak mampu mengenal benda dengan menghubungkan satu benda dengan benda yang lain anak yang mencapai kategori BB sebanyak 4 orang dari 8 anak. anak yang mencapai kriteria masih berkembang MB sebanyak 4 orang dari 8 anak. Anak yang mencapai kriteria BSH dan BSB tidak ada anak yang mencapai kriteria tersebut dari 10 anak. melakukan kegiatan yang menunjukkan anak mampu mengenal benda dengan menghubungkan nama benda dengan tulisan anak yang mencapai kriteria BB sebanyak 4 orang dari 8 anak. anak yang mencapai kriteria MB sebanyak 4 orang dari 8 anak.

Anak yang mencapai kriteria BSH dan BSB tidak ada anak yang mencapai kriteria tersebut dari 8 anak. Sedangkan pada siklus II melepaskan kepingan-kepingan kartu kata berada dalam kategori Baik, karena sebelum anak melakukan proses pembelajaran guru melepaskan kepingan-kepingan kartu kata tersebut. mengacak kepingan-kepingan kartu kata berada dalam kategori baik, karena pada proses pembelajaran guru mengajak kepingan-kepingan tersebut di depan anak-anak serta memperatekkan media tersebut di depan anak-anak. mengajak anak untuk bermain kartu kata berada dalam kategori baik, karena pada proses pembelajaran guru mengajak anak untuk bermain kartu kata dengan 
menarik perhatian anak yaitu dengan mengajukan pertanyaan lebih dulu memberikan tantangan kepada anak untuk menyusun kepingan kartu dengan tepat, menggunakan hitungan angka 1-10 atau stopwatch. berada dalam kategori baik, karena guru memberikan tantangan kepada anak dengan cara menarik, sehingga anak termotivasi dan tertarik untuk menyusun kepingan kartu kata dan gambar. Melakukan kegiatan yang menunjukkan anak mampu mengenal benda dengan menghubungkan satu benda dengan benda yang lain. BB dan MB tidak ada anak yang mencapai kreteria tersebut dari 8 anak. Anak yang mencapai kriteria BSH sebanyak 6 orang dari 8 anak.

Anak yang mencapai kriteria BSB sebanyak 2 anak dari 8 anak. melakukan kegiatan yang menunjukkan anak mampu mengenal benda dengan menghubungkan nama benda dengan tulisan. Anak yang mencapai kriteria BB tidak ada anak yang mencapai kreteria tersebut dari 8 anak. Anak yang mencapai kriteria MB tidak ada anak yang mencapai kreteria tersebut dari 8 anak. Anak yang mencapai kriteria BSH terdapat 7 anak dari 8 anak. sedangkan anak yang mencapai kriteria BSB terdapat 1 anak dari 8 anak.

Dari pelaksanaan kegiatan kartu kata dan gambar pada siklus I dan II, di peroleh hasil yang menunjukkan bahwa meningkatan kemampuan membaca permulaan anak yang di tandai dengan melakukan kegiatan yang menunjukkan anak mampu mengenal benda dengan menghubungkan satu benda dengan benda yang lain. Melakukan kegiatan yang menunjukkan anak mampu mengenal benda dengan meghubungkan nama benda dengan tulisan. Hal ini sejalan dengan dikemukakan oleh. (Ismail, 2006: 181) bahwa Fungsi media kartu kata dan gambar adalah untuk mengenalkan huruf pada anak usia 4-6 tahun dengan lebih cepat. Sebab dengan bantuan alat peraga, guru bukan saja dapat menjelaskan lebih banyak hal dalam waktu yang lebih singkat, juga dapat mencapai hasil yang lebih cepat, Dengan bantuan kartu kata dan gambar, maka anak diharapkan dapat mengenal kata dan dapat mengembangan kemampuan membaca permulaan dengan cepat dengan cara yang menyenangkan.

\section{KESIMPULAN}

Berdasarkan hasil penelitian dan pembahasan yang telah dikemukakan, maka dapat diperoleh kesimpulan bahwa kemampuan membaca permulaan pada anak kelompok B2 usia 5-6 tahun di Taman Kanak- kanak Tadika Ceria BTN Kodam VII Wirabuana Kota Makassar terjadi peningkatkan dengan menggunakan kegiatan melalui kartu kata dan gambar, baik dari aktifitas pembelajaran guru maupun kemampuan membaca permulaan anak, dimana pada siklus I kegiatan guru berada di kategori kurang, dan menjadi kategori baik pada siklus II. Sedangkan kemampuan membaca permulaan anak siklus I menunjukkan anak mampu mengenal benda dengan menghubungkan satu benda dengan benda lain dan melakukan kegiatan yang menunjukkan anak mampu mengenal benda dengan menghubungkan nama benda dengan tulisan berada pada kategori mulai berkembang, dan kemampuan membaca permulaan anak pada siklus II indikator menunjukkan anak mampu mengenal benda dengan menghubungkan satu benda dengan benda lain dan melakukan kegiatan yang menunjukkan anak mampu mengenal benda dengan menghubungkan nama benda dengan tulisan berada pada kategori berkembang sesuai harapan. Melalui kegiatan kartu kata dan gambar dapat meningkatkan kemampuan membaca permulaan. 
6 | TEMATIK, Juni 2019, Volume 5, Nomor 1, Halaman 1-6

\section{DAFTAR PUSTAKA}

Andang Ismail. (2006). Education Games. Yogyakarta: Pilar Media.

Arikunto, Suharsimi dkk. 2007. Penelitian Tindakan Kelas. Jakarta: Bumi Aksara.

Badru Zaman dkk. (2008). Media dan Sumber belajar TK. Jakarta: Universitas Terbuka.

Dina Indriana.2011. Ragam Alat Bantu Media Pengajaran.Yogyakarta:Diva Press.

Dalman. 2003. Keterampilan Membaca. Jakarta: PT Raja Graindo Persada.

Gunarti Widya,dkk. 2008. Metode Pengembangan Perilaku dan Kemampuan Dasar Anak Usia Dini. Jakarta: Universitas Terbuka

Hariwijaya. 2013. Multiple Intelligences Pendekatan Tematis Super Kreatif bagi anak Prasekolah. Yogyakerta: Mitra Buku.

Ika Budi Maryatun. (2011). PAUD dan Pemanfaatan Bahan Bekas untuk APE. Dakses dari http://staff.uny.ac.id/sites/tmp/Pemanfaatan Bahan Bekas.pdf.

Nurbiana Dhieni. 2005. Metode Pengembangan Bahasa. Jakata: Universitas Terbuka

Peraturan Menteri Pendidikan dan Kebudayaan Republik Indonesia Nomor 146 Tahun 2014 tentang Standar Nasional Pendidikan Anak Usia Dini

Rahim Farida. 2008. Pengajaran Membaca Disekolah Dasar. Jakarta: PT Bumi Aksara

Sareb Masri Putra. 2008. Minat membaca Sejak Dini. Jakarta: PT Indeks

Shofi Ummu. 2008. Sayang belajar baca yuk!. (Metode Praktis Mengajar Anak Membaca dan Menulis). Surakarta: Indiva Media Kreasi.

Suharsimi Arikunto. 2006. Prosedur Penelitian suatu pendekatan praktek. Jakarta: PT Rineka Cipta.

Susanto, Ahmad. 2011. Perkembangan Anak Usia Dini: Pengantar dalam Berbagai Aspeknya. Jakarta: Kencana Prenada: Media Group

Suharso dan Ana Retnoningsih. (2009). Kamus Besar Bahasa Indonesia. Edisi Lux. Semarang: Widya Karya

Sugiyono. 2016. Metode Penelitian Pendidikan.Bandung: Alfabeta.

Syamsuardi, S. (2012). Penggunaan Alat Permainan Edukatif (APE) Di Taman KanakKanak PAUD Polewali Kecamatan Tanete Riattang Barat Kabupaten Bone. Publikasi Pendidikan, 2(1).

Tadkiroatun Musfiroh. (2009). Menumbuh Kembangkan Baca Tulis Anak Usia Dini. Jakarta: Grasindo.

Tampubolon.1993.Mengembangkan Minat dan Kebiasaan Membaca pada anak. Bandung: Angkasa

Ungguh Jasa Muliawan.2016. Mengembangkan Imajinasi dan Kreatifitas Anak 